\title{
Effect of a combination of Phaseolus vulgaris L. extract and acarbose on postprandial glucose level after cooked rice intake in healthy volunteers
}

\author{
Robby Zulkarnain ${ }^{1}$, Arini Setiawati², Rianto Setiabudy ${ }^{2}$ \\ 1 Graduated from Post graduate Program of Biomedical Science, Department of Pharmacology \& Therapeutics, Faculty of Medicine, \\ University of Indonesia, Jakarta, Indonesia \\ 2 Department of Pharmacology \& Therapeutics, Faculty of Medicine, University of Indonesia, Jakarta, Indonesia
}

\begin{abstract}
Abstrak
Tujuan Penelitian ini bertujuan untuk mengukur besarnya efek kombinasi ekstrak Phaseolus vulgaris dan akarbose dibandingkan dengan akarbose saja dalam menurunkan kadar glukosa posprandial pada sukarelawan sehat setelah makan nasi.
\end{abstract}

Metode Sampel darah diambil pada waktu-waktu tertentu sampai tiga jam setelah makan nasi. Parameter kadar glukosa posprandial adalah luas area di bawah kurva kadar glukosa terhadap waktu selama tiga jam setelah makan nasi.

Hasil Setelah pemberian kombinasi ini terjadi penurunan luas area di bawah kurva sebesar 21.6\%, sedangkan pada pemberian akarbose terjadi penurunan sebesar $22.9 \%$.

Simpulan Pemberian kombinasi ekstrak Phaseolus vulgaris dosis 1500 mg dan akarbose dosis 50 mg menghasilkan penurunan kadar glukosa posprandial yang tidak bermakna jika dibandingkan pemberian $50 \mathrm{mg}$ akarbose saja. (Med J Indones 2009; 18: 25-30)

\begin{abstract}
Aim This study was aimed to measure the effects of combination Phaseolus vulgaris extract and acarbose compared to acarbose alone on postprandial glucose concentration in healthy volunteers after cooked rice intake.

Methods Blood sample were obtained at several time points up to three hours after cooked rice intake. The parameter for postprandial glucose concentration is the area under the curve (AUC) of glucose concentration vs.time for three hours after cooked rice intake.

Results After taking this combination, postprandial glucose concentration was reduced by $21.6 \%$, while the reduction by acarbose alone was $22.9 \%$.

Conclusions The reduction of postprandial glucose concentration after administration of this combination was not significantly different compared to that after administration of acarbose alone. (Med J Indones 2009; 18: 25-30)
\end{abstract}

Keywords: Phaseolus vulgaris extract, acarbose, postprandial glucose concentration

In many countries, food consumption pattern of people in urban area and its surroundings has changed. Food with high content of fat and carbohydrate is increasingly consumed. At the end it will stimulate excessive weight and degenerative diseases. ${ }^{1}$ Therapies to loose excessive weight are generally conducted by decreasing carbohydrate intake or inhibiting carbohydrate absorption. Plant extracts which inhibit carbohydrate absorption usually contain $\alpha$-amylase inhibitor.

Phaseolus vulgaris extract has been known as containing an $\alpha$-amylase inhibitor, which inhibits hydrolysis of complex carbohydrate. ${ }^{2}$ Several studies already proved that Phaseolus vulgaris extract reduced postprandial blood glucose concentrations..$^{2-4}$
Besides plant extract, many chemical substances can inhibit carbohydrate absorption, one of them is acarbose. ${ }^{5}$ Acarbose is a pseudotetrasaccharide compound derived from fermentation of Actinoplanes utahensis. ${ }^{5-6}$ Acarbose decreases postprandial glucose concentration in patients with diabetes mellitus. ${ }^{5}$ This is achieved by competitive inhibition of disaccharides on $\alpha$-glucosidase enzyme. ${ }^{6}$

To date, no clinical study has been conducted to measure the effect of a combination of Phaseolus vulgaris extract and acarbose on postprandial glucose concentration after cooked rice intake. This study was aimed to measure the effect of this combination compared to acarbose alone in reducing postprandial 
glucose concentration during three hours after cooked rice intake.

\section{METHODS}

The study protocol was approved by the Ethics Committee of the University of Indonesia. The study was carried out in accordance with the principles of Declaration of Helsinki as revised in year 2000, and written informed consent was obtained from each volunteer. No volunteer took medications which might influence the glucose concentration, and all volunteers abstained from alcohol, tobacco, and strenuous activity for 24 hours prior to the study and also coffee-containing beverages.

This study was designed as randomized, crossover and open label. It was performed from November 2007 until February 2008 with 12 volunteers. A combination of $1500 \mathrm{mg}$ Phaseolus vulgaris extract and $50 \mathrm{mg}$ acarbose, or acarbose $50 \mathrm{mg}$ alone was given just prior to cooked rice intake. Blood samples were drawn from each volunteer before and at intervals up to three hours after taking cooked rice. Postprandial glucose concentrations were measured by enzymatic colorimetric "GOD-PAP" method. Then the area under the curves (AUCs) of glucose concentrations versus blood sampling time in control, combination of Phaseolus vulgaris extract and acarbose, and acarbose alone groups were calculated.

Volunteers aged 18 to 55 with BMIs of $18-23 \mathrm{~kg} / \mathrm{m}^{2}$ were enrolled in this study if they already passed the selection criteria, and gave their informed consent. Volunteers were excluded from the study if any of the following conditions was present at screening or baseline visits: pregnant or breast feeding woman, hypersensitivity to Phaseolus vulgaris extract or acarbose, documented gastrointestinal disease likely to be associated with altered absorption of nutrients, history of alcohol abuse, active smokers with more than ten cigarettes per day, taking any medication one week prior to the study, including vitamins, supplements, or traditional drugs, or participation in another study within less than 3 months before the study.

Blood samples were collected from the cubital vein of each volunteer. Whole blood samples were used to determine fasting or postprandial blood glucose. The test drugs in this study were Phaseolamin ${ }^{\circledR}$ capsule containing $500 \mathrm{mg}$ of Phaseolus vulgaris extract (Pharmachem Laboratories, USA) and Glucobay ${ }^{\circledR}$ tablet containing $50 \mathrm{mg}$ of acarbose (PT. Bayer Indonesia). The glucose concentrations were determined using a commercial glucose kit (FS Diasys $\left.{ }^{\circledR}\right)$, whereas the standardized meal was cooked rice with $80 \mathrm{~g}$ carbohydrate content.

\section{Study procedure}

The study was carried out on 3 consecutive mornings. On the first day, after overnight fast, all volunteers received only standardized meal containing $80 \mathrm{~g}$ of carbohydrate. Blood samples were taken at $0,15,30$, $45,60,80,100,120,150$ and 180 minutes after taking cooked rice. On the second day, after overnight fast, all volunteers were divided randomly into two groups. The first group took combination of Phaseolus vulgaris extract and acarbose, and the second group took acarbose alone, followed by standardized cooked rice with $80 \mathrm{~g}$ carbohydrate content. Blood samples were obtained at the same time points as the day before. On the last day, after overnight fast, the first group took acarbose alone while the second group took combination of Phaseolus vulgaris extract and acarbose, followed by standardized cooked rice with $80 \mathrm{~g}$ carbohydrate content. Blood samples were collected at the same time points as the previous two days.

\section{Glucose measurement}

Venous blood samples were obtained in glass tubes, and were immediately separated for serum by centrifugation at $3000 \mathrm{rpm}$ for $10 \mathrm{~min}$. Determination of blood glucose concentrations in serum were done according to GOD-PAP method based on generation of quinoneimine substance. This substance was the result of glucose oxidation by glucose oxidase and was measured at $\lambda 546 \mathrm{~nm}$.

\section{Statistical analysis}

Values were expressed in means and SDs. Two-tailed paired-t test was used to determine whether there was a significant difference between the combination of Phaseolus vulgaris extract and acarbose with acarbose alone in decreasing the postprandial glucose concentration. A probability of $\leq 0.05$ was considered significant. 


\section{RESULTS}

\section{Mean (SD) of glucose serum concentrations}

The baseline characteristics of the 12 volunteers are shown in Table 1. The postprandial glucose concentrations after rice only, after the drug combination and rice, and after acarbose and rice are shown in Figure 1 and Table 2. After the test meal in control group, mean (SD) glucose serum concentrations increased from baseline $74(6) \mathrm{mg} / \mathrm{dL}$ to a peak of $151(12) \mathrm{mg} / \mathrm{dL}$ at 45 min (peak glucose concentration) and returned to baseline at $180 \mathrm{~min}$. After the drug combination and the test meal, glucose serum concentrations increased from baseline $77(8) \mathrm{mg} / \mathrm{dL}$ to a peak of $98(23) \mathrm{mg} / \mathrm{dL}$ at
$60 \mathrm{~min}$ and returned to baseline at $180 \mathrm{~min}$. Meanwhile in acarbose group and test meal, glucose serum concentrations increased from baseline $77(11) \mathrm{mg} / \mathrm{dL}$ to a peak of $102(13) \mathrm{mg} / \mathrm{dL}$ at $30 \mathrm{~min}$ and returned to baseline at $180 \mathrm{~min}$ (see Figure 1 and Table 2).

Table 1. Baseline characteristics of volunteers

\begin{tabular}{llcc}
\hline & & Mean(SD) & Range \\
\hline Sex & $($ Male:Female) & $7: 5$ & \\
Age & $(\mathrm{yr})$ & $30.6(8.6)$ & $19-45$ \\
Weight & $(\mathrm{kg})$ & $57(4)$ & $50-67$ \\
Height & $(\mathrm{cm})$ & $162(5)$ & $154-171$ \\
Body Mass Index & $\left(\mathrm{kg} / \mathrm{m}^{2}\right)$ & $21.5(1.3)$ & $19-23$ \\
\hline
\end{tabular}

Table 2. Mean (SD) of postprandial glucose concentrations from all volunteers in control group, after combination of Phaseolus vulgaris extract and acarbose, and after acarbose alone.

\begin{tabular}{ccccccccccc}
\hline \multirow{2}{*}{ Group } & \multicolumn{8}{c}{ Mean (SD) of postprandial glucose concentrations (mg/dL) at minutes: } \\
\cline { 2 - 11 } & 0 & 15 & 30 & 45 & 60 & 80 & 100 & 120 & 150 & 180 \\
\hline Control & $80(14)$ & $83(21)$ & $124(14)$ & $130(15)$ & $113(27)$ & $98(25)$ & $97(22)$ & $94(12)$ & $90(17)$ & $81(6)$ \\
Combination & $78(8)$ & $82(11)$ & $94(10)$ & $96(17)$ & $98(23)$ & $90(17)$ & $91(12)$ & $87(9)$ & $89(9)$ & $83(9)$ \\
Acarbose & $77(11)$ & $84(9)$ & $102(13)$ & $98(18)$ & $92(20)$ & $89(14)$ & $92(11)$ & $87(11)$ & $86(10)$ & $87(7)$ \\
\hline
\end{tabular}

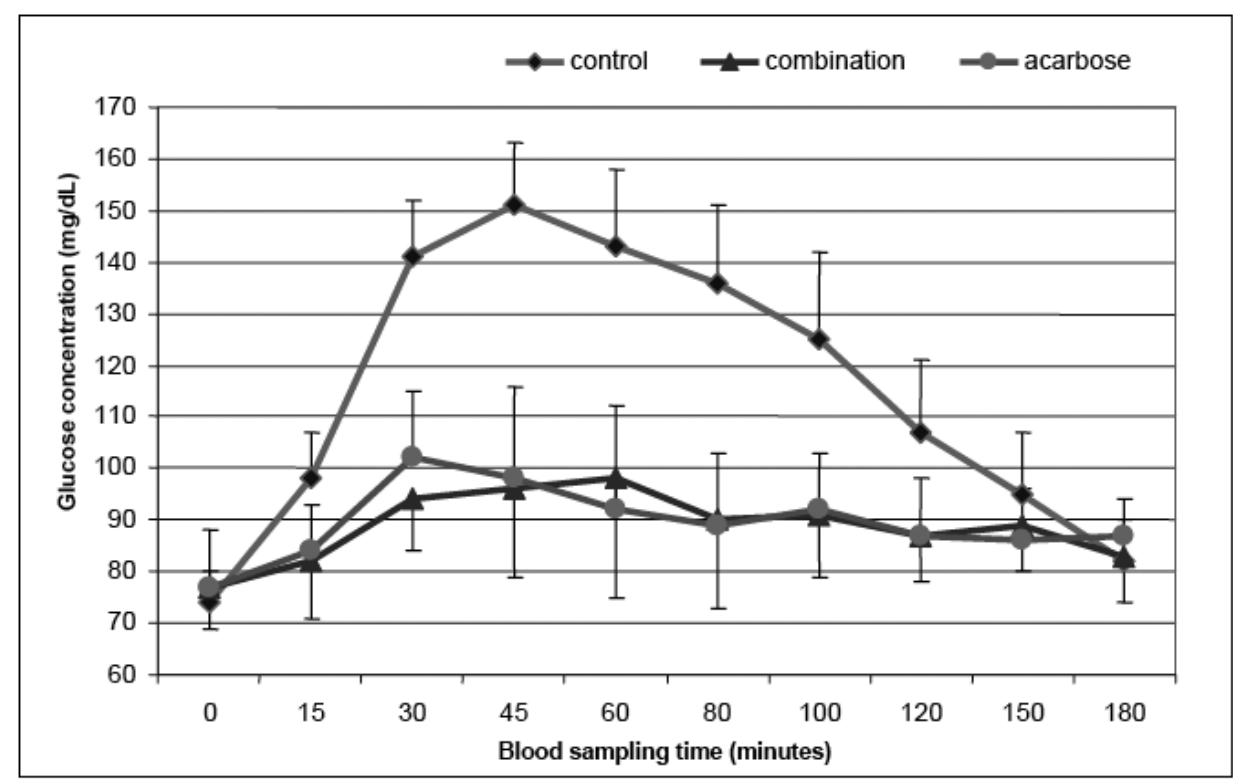

Figure 1. Mean (SD) of postprandial glucose concentrations versus blood sampling time from all volunteers in control group, after combination of Phaseolus vulgaris extract and acarbose, and after acarbose alone. 


\section{Area under the curve of glucose serum concentrations}

The present study demonstrated that area under the curve of acarbose group was the smallest, followed by combination group, and that of control group was the largest (See Figure 2). The combination of Phaseolus vulgaris extract and acarbose caused $27.6 \%$ reduction of postprandial glucose concentrations, while acarbose alone caused $29.7 \%$ reduction. The result of paired-t test comparing the combination and acarbose alone was not significantly different (Table 3 ). No adverse event was observed during the study.

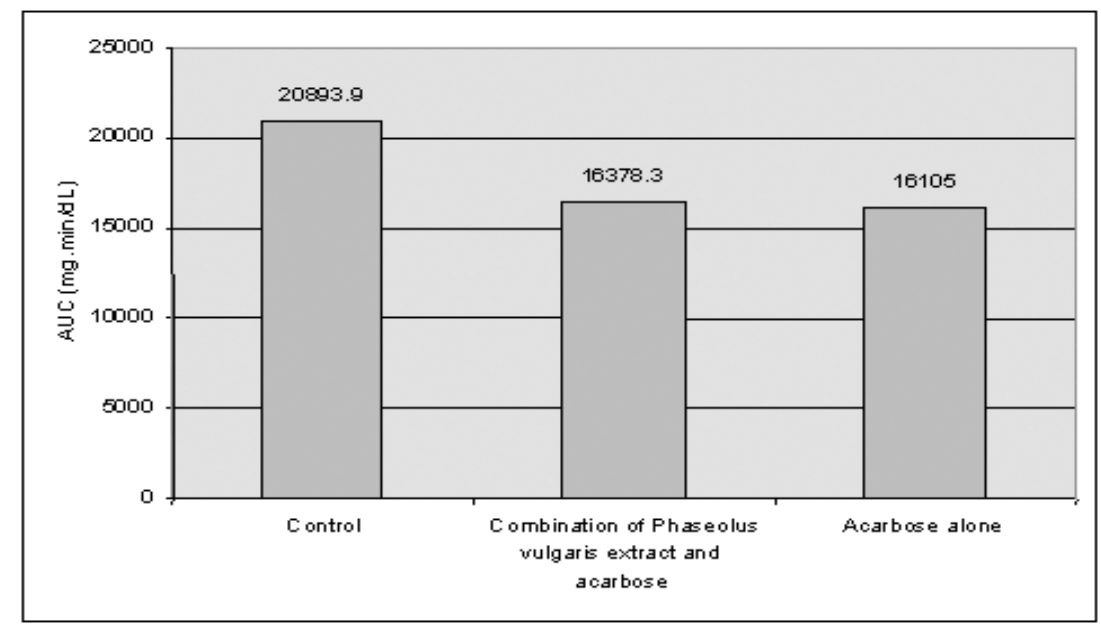

Figure 2. Mean of Area Under Curve (AUC) from all olunteers in control, after combination of Phaseolus vulgaris extract and acarbose, and after acarbose alone.

Table 3. Area Under the Curve $\left(\mathrm{AUC}_{0-3 \mathrm{~h}}\right)$ of control, after combination of Phaseolus vulgaris extract and acarbose, and after acarbose alone, with their differences in each volunteer.

\begin{tabular}{|c|c|c|c|c|c|c|}
\hline \multirow[t]{2}{*}{ Volunteer No. } & \multicolumn{3}{|c|}{$\mathrm{AUC}$ (mg.min/dL). } & \multirow{2}{*}{$\begin{array}{l}\text { Difference } \\
\text { of Control- } \\
\text { Combination } \\
(\mathrm{KK})(\%)\end{array}$} & \multirow{2}{*}{$\begin{array}{l}\text { Difference } \\
\text { of Control } \\
\text {-Acarbose } \\
(\mathrm{KA})(\%)\end{array}$} & \multirow{2}{*}{$\begin{array}{l}\text { Difference of } \\
\text { KK-KA }(\%)\end{array}$} \\
\hline & Control & $\begin{array}{c}\text { Combina } \\
\text { tion }\end{array}$ & Acarbose & & & \\
\hline 1 & 20958 & 16470 & 15773 & 21.4 & 24.7 & -3.3 \\
\hline 2 & 22718 & 16980 & 17763 & 25.3 & 21.8 & 3.4 \\
\hline 3 & 19598 & 13273 & 14738 & 32.3 & 24.8 & 7.5 \\
\hline 4 & 19935 & 16375 & 15015 & 17.9 & 24.7 & -6.8 \\
\hline 5 & 19200 & 14215 & 13973 & 26.0 & 27.2 & -1.3 \\
\hline 6 & 20378 & 16670 & 17493 & 18.2 & 14.2 & 4.0 \\
\hline 7 & 22865 & 15940 & 15783 & 30.3 & 31.0 & -0.7 \\
\hline 8 & 19203 & 18213 & 18393 & 5.2 & 4.2 & 0.9 \\
\hline 9 & 22805 & 15100 & 15013 & 33.8 & 34.2 & -0.4 \\
\hline 10 & 21638 & 18878 & 18413 & 12.8 & 14.9 & -2.1 \\
\hline 11 & 21028 & 15100 & 14610 & 28.2 & 30.5 & -2.3 \\
\hline 12 & 20405 & 18878 & 16298 & 7.5 & 20.1 & -12.6 \\
\hline Mean & 20894 & 16378 & 16105 & 21.6 & 22.7 & -1.1 \\
\hline $\mathrm{SD}$ & 1358 & 1692 & 1553 & 9.5 & 8.4 & 5.2 \\
\hline Median & 20681 & 16423 & 15778 & 14.4 & 22.4 & -8.0 \\
\hline Normality (KS) & $\mathrm{p}=0.200(\mathrm{NS})$ & $\mathrm{p}=0.200(\mathrm{NS})$ & $\mathrm{p}=0.200(\mathrm{NS})$ & $\mathrm{p}=0.200(\mathrm{NS})$ & $\mathrm{p}=0.200(\mathrm{NS})$ & $\mathrm{p}=0.200(\mathrm{NS})$ \\
\hline Paired-t & & & & -0.74 & (NS) & \\
\hline
\end{tabular}

NS: not significantly different; KS: Kolmogorov-Smirnov test 


\section{DISCUSSION}

The results of the present study showed that combination of Phaseolus vulgaris extract and acarbose or acarbose alone decreased postprandial glucose concentrations significantly from control. This decline in postprandial glucose concentrations was due to inhibition of carbohydrate degradation by both test drugs. Phaseolus vulgaris extract inhibits degradation of complex carbohydrate to disaccharides. These effects have been proven in several studies. ${ }^{2-4}$ Meanwhile acarbose reduces postprandial glucose concentration through inhibition of $\alpha$-glucosidase enzyme..$^{5-6}$

Phaseolus vulgaris extract reduces postprandial glucose concentration because it contains inhibitors of $\alpha$-amylase enzyme ( $\alpha$-AIs), which can be differentiated to 3 isoforms: $\alpha-\mathrm{AI}_{1}, \alpha-\mathrm{AI}_{2}$, and $\alpha-\mathrm{AI}_{3}$. These isoforms can bind 4 from 5 binding sites which are located in $\alpha$-amylase enzyme. ${ }^{7}$ These binding sites are Thr163 at binding site I, His101 and Asp197 at binding site III, His201, Glu233 and Asp300 at binding site IV, and Tyr151, Lys200 and Glu240 at binding site V. ${ }^{7}$ Le-Berre Anton et al. ${ }^{8}$ showed that $\alpha$-AIs isoforms cause $90 \%$ reduction of $\alpha$-amylase enzyme activities. Desseaux et al. ${ }^{9}$ showed that Phaseolus vulgaris extract inhibited $\alpha$-amylase from saliva and $\alpha$-amylase from pancreas because it formed abortive complex consisting of enzyme, inhibitor, and substrate.

Addition of $50 \mathrm{mg}$ acarbose to Phaseolus vulgaris extract was expected to decrease postprandial glucose level even more. However, this combination yielded only $21.6 \%$ reduction and this was lower compared to $22.9 \%$ reduction by acarbose alone. These results were unexpected. We could not find exactly why. It was thought that there was competition between Phaseolus vulgaris extract and acarbose to bind with $\alpha$-amylase. ${ }^{10}$

Acarbose $50 \mathrm{mg}$ alone caused $22.9 \%$ decrease in postprandial glucose concentration. This result was thought to derive from inhibition of sequential digestive enzymes in carbohydrate digestion. Acarbose inhibits not only $\alpha$-glucosidase but also inhibits other digestive enzymes, like $\alpha$-amylase, $\alpha$-maltase, $\alpha$-isomaltase, $\alpha$-glucoamylase, and $\alpha$-sucrase. ., 10

Some studies have compared the binding of acarbose to $\alpha$-amylase with that of Phaseolus vulgaris extract. Koukiekolo $^{10}$ showed that acarbose had stronger potency in inactivating $\alpha$-amylase enzyme compared to Phaseolus vulgaris extract. Acarbose required only 0.4 $\mathrm{mg} / \mathrm{dL}$, while extract of Phaseolus vulgaris required $2.7 \mathrm{mg} / \mathrm{dL}$ to inactivate $\alpha$-amylase enzyme. Nahoum et $a .^{7}$ showed that acarbose bound to all binding sites in $\alpha$-amylase enzyme, while Phaseolus vulgaris extract bound only 4 from 5 binding sites in $\alpha$-amylase.

The ability of acarbose to bind $\alpha$-amylase enzyme and inhibit degradation of carbohydrate was also supported by studies by Brayer et al. ${ }^{11}$, Kagawa et al. ${ }^{12}$, and Oudjeriouat et al. ${ }^{13}$ Brayer et al. ${ }^{11}$ showed that acarbose bound $\alpha$-amylase enzyme through reaction of hydrolysis and transglycosylation of acarbose structure in the form of pentasaccharide at Asp197, Glu233 and Asp300. Kagawa et al. ${ }^{12}$ demonstrated that acarbose made a permanent complex structure with $\alpha$-amylase enzyme and substrate. Oudjeriouat et al. ${ }^{13}$ showed inhibition of $\alpha$-amylase by acarbose which acted as analogous compound of transition and bound $\alpha$-amylase in its active center at Trp206 and Trp276-277.

Shimabukuro et al. ${ }^{14}$ showed that a single dose of 100 $\mathrm{mg}$ acarbose caused 13\% reduction of postprandial glucose level; this result was different from the result of the present study. This difference in reduction of postprandial glucose level may be due to differences in the standard food, the dose of acarbose used, and the volunteers involved. The difference in standard food can be seen from the carbohydrate content. Cooked rice with $80 \%$ carbohydrate content was used as the source of carbohydrate in the present study, while Shimabukuro et al. ${ }^{14}$ used standard food with $50 \%$ carbohydrate content. The dose of acarbose used by Shimabukuro et al. ${ }^{14}$ was $100 \mathrm{mg}$ in diabetes mellitus patients while the dose of acarbose used in the present study was $50 \mathrm{mg}$ in healthy volunteers. Patients with diabetes mellitus usually have different mechanism of carbohydrate absorption from healthy volunteers. Generally the intestinal tract of diabetic patients have delayed absorption of carbohydrate caused by the pathology of diabetes, thereby the effect of acarbose in inhibiting postprandial glucose level absorption in these patients is lower although using larger dose compared to healthy volunteers. ${ }^{15}$

The difference in the degradation of postprandial carbohydrate to glucose in each volunteer may also be influenced by other factors such as body response to food intake, whereas genetic factors such as genetic polymorphism of glucose transporter may influence glucose absorption. Besides the above-mentioned factors, many other factors may also influence carbohydrate absorption in the digestive tract, for 
example the gastric emptying time, the surface area in the small intestine for glucose absorption, the duration of carbohydrate transit in the digestive tract, and the activities of $\alpha$-glucosidase enzyme. However, the influence of most of these factors have been eliminated by the application of cross-over design in this study, in which each volunteer serves as his/her own control.

\section{CONCLUSION}

The result of the present study has showed that reduction of postprandial glucose concentration by the combination of Phaseolus vulgaris extract and acarbose is not significantly different from that by acarbose alone.

\section{Acknowledgements}

This study was funded in part by a grant from PT. Kalbe Farma Tbk. We appreciate and express our thanks to the study personnel for their commitment and to all volunteers for their participation in this study.

\section{REFERENCES}

1. Cummings DE, Shannon MH. Roles for ghrelin in the regulation of appetite and body weight. Arch Surg. 2003; 138(4): 389--96.

2. Widjaja I. Efek ekstrak Phaseolus vulgaris dalam menurunkan absorpsi karbohidrat setelah makan nasi [tesis]. Jakarta: Universitas Indonesia; 2006.

3. Udani J, Hardy M, Madsen DC. Blocking carbohydrate absorption and weight loss: a clinical trial using Phase 2, brand proprietary fractionated white been extract. Altern Med Rev. 2004; 9(1): 63-9.

4. Lumbuun N. Efek jamu Diabet ${ }^{\circledR}$ untuk menurunkan kadar glukosa darah pada sukarelawan sehat [tesis]. Jakarta: Universitas Indonesia;2006.
5. Arky R, Davidson CS. Physicians` Desk Reference. New York: $58^{\text {th }}$ ed. Medical Economics; 2004, p. 3005.

6. Holman R, Turner R, Cull CA. A randomized double blind trial of acarbose in type 2 diabetes shows improved glycemic control over 3 years: clinical prospective diabetes study. Diab Care. 1999; 22(6): 960-4.

7. Nahoum V, Roux G, Anton V, Rouge P, Puigserver A, Bishchoff $\mathrm{H}$, et al. Crystal structures of human pancreatic $\alpha$-amylase in complex with carbohydrate and proteinaceous inhibitors. Biochem J. 2000; 346: 201-8.

8. Le Berre-Anton V, Bompard-Gilles C, Payan F, \& Rouge P, Characterization and functional properties of the $\alpha$-amylase inhibitor $(\alpha-\mathrm{AI})$ from kidney bean (Phaseolus vulgaris) seeds. Biochem Biophys Act. 1997; 1343: 31-40.

9. Desseaux V, Koukiekolo R, Moreau Y, Santimone M, Marchis-Mouren G, Mechanism of porcine pancreatic $\alpha$-amylase: inhibition of amylase and malto pentose hydrolysis by various inhibitors. Biol. Bratislava. 2002; 57(Suppl 11): 463-70.

10. Koukiekolo R, Le Berre AV, Desseaux V, Morreau Y, Rouge P, Marchis-Mouren G, et.al. Mechanism of porcine pancreatic $\alpha$-amylase: inhibition of amylase and maltopentose hydrolysis by kidney bean (Phaseolus vulgaris) inhibitor and comparison with that by acarbose. Eur J Biochem. 1999; 265: 20-6.

11. Brayer GD, Sidhu G, Maurus R, Rydberg EH, Braun C, Wang Y, et.al. Sub site mapping of the human pancreatic a-amylase active site through structural, kinetic and mutagenesis techniques. Biochemistry. 2000; 39: 4778-91.

12. Kagawa M, Fujimoto Z, Momma M, Takase K, Mizuni H. Crystal structure of Bacillus subtilis-amylase in complex with acarbose. J Bacteriol. 2003; 185(23): 6981-4.

13. Oudjeriouat N, Morreau Y, Santimone M, Svensson B, Marchis-Muren G, Desseaux V. On the mechanism of $\alpha$-amylase: Acarbose and cyclodextrin inhibition of barley amylase isoenzymes. Eur J Biochem. 2003; 270: 3871-9.

14. Shimabukuro M, Higa N, Chinen I, Yamakawa K, Takasu N. Effects of a single administration of acarbose on postprandial glucose excursion and endothelial dysfunction in type 2 diabetic patients: a randomized crossover study. J Clin End Metab. 2006; 91(3): 837-42.

15. Horowitz M, Fraser R. Disorderes gastric motor function in diabetes mellitus. Diabetologia. 1994; 37: 543-51. 